\title{
In situ effects of simulated overfishing and eutrophication on settlement of benthic coral reef invertebrates in the Central Red Sea
}

In the Central Red Sea, healthy coral reefs meet intense coastal development, but data on the effects of related stressors for reef functioning are lacking. This in situ study therefore investigated the independent and combined effects of simulated overfishing through predator/grazer exclusion and simulated eutrophication through fertilizer addition on settlement of reef associated invertebrates on light-exposed and -shaded tiles over 4 months. At the end of the study period invertebrates had almost exclusively colonized shaded tiles. Algae were superior settling competitors on light-exposed tiles. On the shaded tiles, simulated overfishing prevented settlement of hard corals, but significantly increased settlement of polychaetes, while simulated eutrophication only significantly decreased hard coral settlement relative to controls. The combined treatment significantly increased settlement of bryozoans and bivalves compared to controls and individual manipulations, but significantly decreased polychaetes compared to simulated overfishing. These results suggest settlement of polychaetes and hard corals as potential bioindicators for overfishing and eutrophication, respectively, and settlement of bivalves and bryozoans for a combination of both. Therefore, if the investigated stressors are not controlled, phase shifts from dominance by hard corals to that by other invertebrates may occur at shaded reef locations in the Central Red Sea. 


\section{In situ effects of simulated overfishing and eutrophication on \\ 2 settlement of benthic coral reef invertebrates in the Central \\ 3 Red Sea}

4 Christian Jessen ${ }^{1, *}$, Christian R. Voolstra ${ }^{2}$ and Christian Wild ${ }^{1,3}$

$5 \quad{ }^{\prime}$ Coral Reef Ecology Group (CORE), Leibniz Center for Tropical Marine Ecology, Fahrenheitstr.

6 6, 28359 Bremen, Germany

$7 \quad{ }^{2}$ Red Sea Research Center, King Abdullah University of Science and Technology (KAUST),

8 23955-6900 Thuwal, Saudi Arabia

$9{ }^{3}$ Faculty of Biology and Chemistry, University of Bremen, Germany

10 * corresponding author

11 email: christian.jessen@zmt-bremen.de

12 phone: $+49(0) 42123800106$

13 fax: $+49(0) 4212380030$

14 keywords: recruitment, sessile invertebrates, nutrient enrichment, overfishing, bioindicators,

15 settlement, Red Sea, coral reef. 
16

\section{Abstract}

In the Central Red Sea, healthy coral reefs meet intense coastal development, but data on the effects of related stressors for reef functioning are lacking. This in situ study therefore investigated the independent and combined effects of simulated overfishing through predator/grazer exclusion and simulated eutrophication through fertilizer addition on settlement of reef associated invertebrates on light-exposed and -shaded tiles over 4 months. At the end of the study period invertebrates had almost exclusively colonized shaded tiles. Algae were superior settling competitors on light-exposed tiles. On the shaded tiles, simulated overfishing prevented settlement of hard corals, but significantly increased settlement of polychaetes, while simulated eutrophication only significantly decreased hard coral settlement relative to controls. The combined treatment significantly increased settlement of bryozoans and bivalves compared to controls and individual manipulations, but significantly decreased polychaetes compared to simulated overfishing. These results suggest settlement of polychaetes and hard corals as potential bioindicators for overfishing and eutrophication, respectively, and settlement of bivalves and bryozoans for a combination of both. Therefore, if the investigated stressors are not controlled, phase shifts from dominance by hard corals to that by other invertebrates may occur at shaded reef locations in the Central Red Sea. 


\section{Introduction}

34 Overfishing and eutrophication are among the most serious local stressors for coral reefs,

35 worldwide and in the Red Sea (Burke et al. 2011). These stressors can strongly affect invertebrate

36 settlement. Settlement (i.e., the permanent attachment to the substratum) of sessile invertebrate

37 larvae is an irreversible process and is thus of critical importance for invertebrate life-cycles

38 (Harrison \& Wallace 1990).

39 Invertebrate settlement can be influenced by numerous factors such as water flow (Mullineaux \&

40 Garland 1993), abundance and composition of microbial biofilms (Hadfield 2011; Sawall et al.

41 2012; Tran \& Hadfield 2011), benthic macroalgae (Arnold et al. 2010; Harrington et al. 2004;

42 O'Leary et al. 2012), conspecific adult invertebrates (Osman \& Whitlatch 1995), predators and

43 grazers (Connell \& Anderson 1999; Glynn 1990; Lewis \& Anderson 2012), or changing

44 environmental conditions that provide competitive advantages to certain species (Hallock \&

45 Schlager 1986).

46 Eutrophication, the increase in nutrient availability influences biofilm diversity and composition

47 (Kriwy \& Uthicke 2011; Webster et al. 2004; Witt et al. 2012a; Witt et al. 2012b). Further,

48 eutrophication and overfishing (of herbivores) can also increase growth of benthic macroalgae

49 such as filamentous algae (Jessen et al. 2013a), thereby providing the faster growing algae with a

50 competition advantage over invertebrates, allowing them to take over suitable substrata. In

51 contrast, some slow growing algae such as crustose coralline algae (CCA), important for coral

52 recruitment (Harrington et al. 2004; Heyward \& Negri 1999), can be suppressed through reduced

53 grazing (Jessen et al. 2013a). Additionally, the increase of certain filter feeders was linked to

54 eutrophication and concomitant increase in organic matter in the water column that made them

55 able to outcompete and prevent settlement of adjacent organisms (Chadwick \& Morrow 2011;

56 Hallock \& Schlager 1986). 
57 Further, overfishing can influence trophic interactions in two ways. Either, by reducing the

number of herbivores and invertebrate predators and therefore freeing macroalgae and certain invertebrates of their top-down control (Birkeland 1977; Birrell et al. 2005; Diaz-Pulido et al. 2010; Osman \& Whitlatch 1995; Vine 1974). Similarly the reduction of predators can result in the release of top-down control of invertebrate feeders such as sea urchins (Hay 1984; McClanahan \& Shafir 1990). As a consequence, the amount of invertebrate settlement can be strongly reduced (Myers et al. 2007), sometimes even down to almost zero (Vine \& Bailey-Brock 1984). Overfishing can furthermore lead to increased bioerosion rates (Tribollet \& Golubic 2011) that reduce suitable settlement habitat for new invertebrate settlement.

Although the top-down and bottom-up effects of overfishing and eutrophication have been intensively studied for benthic reef algal growth and development (e.g., Burkepile \& Hay 2006, Smith et al. 2010, Jessen et al. 2013a), there are few studies that investigated the individual or combined impact on tropical sessile invertebrate settlement in this context. Only Tomascik (1991) and Hunte \& Wittenberg (1992) looked at coral settlement patterns along an eutrophication gradient, although it is not clear if the observed influence was due to altered larval supply. Additionally, our understanding of the ecology of coral reefs in the Red Sea is largely focused on studies conducted in the Gulf of Aqaba, but not in the remaining Red Sea (Berumen et al. 2013). Over 4 months this study simulated a) overfishing by excluding larger predators and herbivores through cages and b) eutrophication through the deployment of nutrient sources in an offshore reef in the Central Red Sea. We wanted to answer the question of how the individual and combined effects of overfishing and eutrophication impact the settlement of main sessile invertebrate groups. 


\section{Materials \& Methods}

80 Study site

81 The study was carried out over 16 weeks from June to September 2011 at the patch reef Al-Fahal

82 that lies about $13 \mathrm{~km}$ off the Saudi Arabian coast in the Central Red Sea (N22.18.333,

83 E38.57.768; see Jessen et al. 2012 for a map of the location). We selected this reef because of its

84 relatively large distance from shore and presumably low impacts from potential fishing and land-

85 derived nutrient import. The reef is characterized by high herbivore fish $\left(22 \mathrm{~g} \mathrm{~m}^{-2}\right)$ and sea urchin

86 biomass $\left(38 \mathrm{~g} \mathrm{~m}^{-2}\right)$, low ambient concentrations of dissolved inorganic nitrogen $\left(\mathrm{DIN}=\mathrm{NH}_{4}^{+}\right.$

$\left.87+\mathrm{NO}_{3}^{-}+\mathrm{NO}_{2}{ }^{-} ; 0.9-1.8 \mu \mathrm{mol} \mathrm{L}{ }^{-1}\right)$, soluble reactive phosphorous $\left(\mathrm{SRP}=\mathrm{PO}_{4}{ }^{3-} ; 0.06-0.10 \mu \mathrm{mol} \mathrm{\textrm {L } ^ { - }}\right.$

$88^{1}$ ), dissolved organic carbon (DOC; $55-67 \mu \mathrm{mol} \mathrm{L}^{-1}$ ), and relatively high live coral cover $(49 \%$

89 hard and soft coral cover; for full results see Jessen et al. 2013a).

90 Experimental setup

91 Ten terracotta tiles (plus two spare tiles) each $10 \times 10 \mathrm{~cm}\left(100 \mathrm{~cm}^{2}\right)$ were mounted on stainless 92 steel screws at an angle of 45 degrees on each of 16 polyvinyl chloride (PVC) frames $(50 \times 75$ $93 \mathrm{~cm}$; in total 160 tiles) approximately $10 \mathrm{~cm}$ above the reef substrate at 5-6 m water depths (Fig. 1) 94 and accessible to invertebrate herbivores (pers. obs.). Tiles were installed in 2 rows with a 95 distance between 3 to $50 \mathrm{~cm}$ (Fig. 1). PVC frames were separated by $2-5 \mathrm{~m}$. Prior to the start of 96 the experiment, tiles were autoclaved to remove any interfering compounds that could have 97 accumulated during tile production. Tiles were installed pairwise on top of each other with 98 unglazed sides facing outside, resulting in an upper (light exposed) and lower (shaded) tile (Fig.

99 1). We applied four different treatments to the frames (each with $n=4)$ : (1) control (only the 100 equipped frame), (2) fertilizer (see nutrient enrichment section), (3) cage (hemispherical zinc 
101

102

103

104

105

106

107

108

109

110

111

112

113

114

115

116

117

118

119

120

121

122

123

124

galvanized cages with a mesh size of $4 \mathrm{~cm}$ and a diameter of $100 \mathrm{~cm}$ ), and (4) a combination of cage and fertilizer tubes.

The cages served to exclude larger predators and herbivores, as overfishing is rather affecting larger species. Smaller fish (small damselfish, parrotfish, wrasses and surgeonfish) were still able to access the insides of the cages. Cage controls were not used, since studies showed that similar cages even with a lower mesh size did not affect water movement, light availability, and

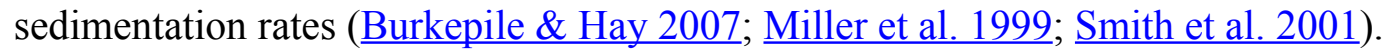

Eutrophication was simulated by deploying four fertilizer tubes around the frame, consisting of perforated PVC tubes filled with approximately $580 \mathrm{~g}$ Osmocote fertilizer (Scotts, $15 \%$ total nitrogen (in form of nitrate \& ammonium), $9 \%$ phosphate (phosphoric pentoxide), and $12 \%$ potassium oxide) embedded in $3 \%$ agarose. Fertilizer was deployed once without replenishments, but regular monitoring of nutrient concentrations assured continuous release rates.

Treatments were not randomly assigned to the frames, instead the sequence control, fertilizer, cage, combination was repeated four times along the reef to control for potential biases such as microhabitats.

One pair of tiles (light-exposed and shaded) per frame was collected after 1, 2, 4, 8, and 16 wk(s) using SCUBA. To facilitate tile division under water tiles were pre-scored (notched) on their glazed side with the help of a tile cutter before the start of the experiments (Fig. 1). Upon sampling, tiles were divided in half (each $50 \mathrm{~cm}^{2}$; an area which had been shown to be large enough from asymptotes of species-area curves by Hixon \& Brostoff 1996) and then wrapped separately in ziplock bags. They were brought on board within $30 \mathrm{~min}$ and half of them was immediately flash frozen in liquid nitrogen for subsequent microbial analyses (results reported elsewhere), while the other half was handled as described below. 
125 To test the success of fertilization, water samples $(5 \mathrm{~L})$ were taken directly before collecting tiles

126 at each time point with large ziplock bags directly from above each frame (in total $\mathrm{n}=40$ for

127 nutrient enriched as well as non-enriched samples). From this stock $50 \mathrm{~mL}$ were filtered on pre-

128 combusted Whatman-GF/F filters and used for inorganic nutrient measurements. The analyses of

129 DIN and SRP were performed using continuous flow analyzer (FlowSys Alliance Instruments).

\section{Invertebrate identification and enumeration}

In order to remove attached sediment, precipitates, and mobile invertebrates, light-exposed and shaded tiles were rinsed with fresh water. Invertebrate classification was conducted with a dissection microscope (Zeiss Stemi 2000; 7.7-fold magnification). All sessile invertebrates visible under the dissection microscope were identified with the help of Vine (1986) and grouped to the following easily distinguishable categories: Scleractinia (Cnidaria), Bivalvia (Mollusca), Bryozoa, and Polychaeta (Annelidae). We counted single animals (Scleractinia, Bivalvia, and polychaetes, such as Spirorbis sp. or Pomatoceros sp.) or colonies (Bryozoa and other polychaetes, such as Filograna sp.) on each tile to quantify the number of individual settlement events. It is likely that other factors than settlement such as competition, predation, and overgrowth affect the number of organisms in the course of the study. However, by considering only sessile and calcareous organisms and thoroughly searching the surface using a dissection microscope, we tried to minimize potential biases as much as possible. Nevertheless, numbers can be slightly underestimated, since we cannot rule out that settlers arrived but did not persist.

Algal composition and algal biomass (only light-exposed tiles) was determined in the laboratory after invertebrate counting by taking pictures of submerged tiles and analyzing them using 100 randomly overlaid points using Coral Point Count with Excel extensions (CPCe) 4.1 (Kohler \& Gill 2006). Primary algal groups were filamentous algae and non-coralline crusts on lightexposed tiles and crustose coralline algae (CCA) and non-coralline red crusts (such as 
149

150

151

152

\section{Statistical data analysis}

154 T-tests were used for analyzing inorganic nutrient concentrations at each sampling point. To meet 155

Peyssonnelia) on shaded tiles. Foliose macroalgae such as Padina, Lobophora, or Halimeda were not found. See Jessen et al. (2013a) for full results of algal cover.

Data of 1 of 16 frames (No. 4, combined treatment) was removed from the dataset, as cage pictures and tile appearance indicated access of large predators and herbivores to this setup.

$$
\text { assumptions of normal distribution DIN-data were inverse square root (1/sqrt(x)) transformed. }
$$

All invertebrate groups were tested for the individual and interactive effects of cage, fertilizer, and time with a 3-factorial generalized linear model (GLM) in R (R development core team 2012). To cope with over- and underdispersion we used either quasi-GLM models (hard corals, polychaetes) or negative binomial model (Bivalvia, Bryozoa), depending which model fit the data better based on pseudo- $\mathrm{R}^{2}$ scores (Zuur et al. 2009). For comparison of the different treatments, we used Tukey post hoc tests ('glht' function) of the 'multcomp' package. 
162

163

164

165

166

167

168

169

170

171

172

173

174

175

176

177

178

179

180

181

182

183

\section{Results}

The simulation of eutrophication constantly and significantly increased SRP concentrations compared to the controls (Fig. S1). DIN concentrations were also constantly increased, but did not always significantly differ from the controls (Fig. S1). Both, ambient and enriched treatments experienced a peak in DIN concentrations after 4 weeks.

Over the sampling period of 16 weeks, $99.9 \%$ of all observed sessile invertebrates settled on the shaded tiles. The exceptions were 1 hard coral recruit (control 2 wks), 5 polychaetes (1x control 2 wks; $3 x$ fertilizer 4 wks; 1x combined 8 wks), and 2 bryozoan colonies (cage 16 wks). Because of this one-sided distribution, the following results stem exclusively from invertebrate observations of the shaded tiles (total 6,862 counts, and an average of 91 counts per shaded tile). Fig. 3 shows representative photographs of light-shaded tiles after 16 weeks of deployment in the reef.

On a temporal scale, polychaetes occurred first after 1 week, bryozoans after 2 weeks, hard corals after 4 weeks, and bivalves after 8 weeks, however, there was no treatment-specific pattern when first settlement occurred (Fig. 2B, D, F, H). Other potential sessile invertebrate groups such as sponges, soft corals, crustaceans, and ascidians were not observed on the analyzed tiles, however the latter group appeared once on a spare tile after 16 weeks.

On the controls, all observed invertebrate groups were present at their lowest abundance compared to the other treatments, except hard coral settlement which was highest in this treatment. (Fig. 2A).

Simulated overfishing reduced hard coral numbers to zero (Fig. 2A), but significantly increased settlement of polychaetes (Fig. 2G). However, simulated overfishing did not show any significant effects on settlement of bryozoans and bivalves (Fig. 2C \& E). 
184 Under simulated eutrophication, hard coral settlement was significantly decreased by 11-fold 185 relative to controls (Fig. 2A), while bryozoans, bivalves, and polychaetes were not significantly 186 affected by this treatment (Fig. 2C-H).

187 The combination of manipulated eutrophication and overfishing significantly increased 188 settlement of bryozoans and bivalves 7 and 11-fold relative to controls (Fig. 2C \& E). Relative to 189 simulated overfishing, the combined treatment significantly increased settlement of bryozoans 4190 fold and that of bivalves 11-fold, but decreased settlement of polychaetes 2-fold, while settlement 191 of hard corals was not affected. Relative to simulated eutrophication, the combined treatment 192 significantly increased settlement of bryozoans 3-fold and bivalves 7-fold, while settlement of 193 hard corals and polychaetes was not affected.

194 Except for bryozoans, all other groups showed significant interaction effects, i.e,. their response 195 to one manipulated factor depended on the level of the other factor (Fig. 2, Table S1). 
196

197

198

199

200

201

202

203

204

205

206

207

208

209

210

211

212

213

214

215

216

217

218

\section{Discussion}

Simulated overfishing increased settlement of polychaetes compared to controls. These observations are concordant with Vine (1974), who observed increased spirorbid settlement in caged treatments. Interestingly, the positive effect of simulated overfishing on settlement of polychaetes was not visible in the combined treatment with increased nutrient availability. A possible explanation could be the presence of heterospecific invertebrates (i.e., bryozoans, bivalves) that can suppress settlement in their vicinity (Osman \& Whitlatch 1995). This hypothesis is supported by the fact that the different polychaete settlement responses between simulated overfishing and combined treatments were not visible before the occurrence of bryozoans and bivalves, which started after 8 weeks.

Simulated eutrophication alone only caused decrease of hard coral settlement, while all other invertebrates were neither positively nor negatively affected by this treatment. This finding is confirmed by the studies of Tomascik (1991) and Hunte \& Wittenberg (1992), who also observed less hard coral settlement in eutrophic reefs and suggest that eutrophic conditions may alter the complex set of physical, chemical and/or biological signals that trigger settlement of coral larvae. However, it is not clear if such differences were caused by negative settlement behavior, postsettlement mortality, or reduced larval supply (i.e., reduced coral fecundity) as observed by Loya et al. (2004) as a response to eutrophication. Large differences in functional algal cover between simulated eutrophication and control treatments did not exist (Jessen et al. 2013a). However, algae species were not identified on the species level, but potential differences on that level therefore may have occurred and influenced the settlement as shown for coralline algae by Harrington et al. (2004). Furthermore, as shown for coral fragments in a parallel experiment (Jessen et al. 2013b), increased nutrient concentrations may have altered the microbial 
219 community structure of biofilms, thereby changing chemical and structural cues that influence

220 settlement.

221 The combination of manipulated overfishing and eutrophication resulted in the highest settlement

222 numbers of bivalves and bryozoans, that were both significantly increased compared to 223 manipulated overfishing and eutrophication treatments. However, algal cover, an important 224 settlement cue, did not substantially vary between combined and simulated overfishing 225 treatments ( $\underline{\text { Jessen et al. 2013a) }}$. We propose therefore that the observed differences were due to 226 a) indirect interaction effects of predator/herbivore exclusion, b) differences in bacterial and 227 diatom biofilm composition (Dahms et al. 2004; Yang et al. 2013) and c) effects of microalgae 228 benefiting from increased nutrients (Posey et al. 2002).

In this study, sessile invertebrates settled almost exclusively on shaded, compared to lightexposed tiles. This light exposure-specific pattern has been confirmed for corals by studies from other reefs (Birkeland 1977; Harrison \& Wallace 1990; Sawall et al. 2013), and contrasts the presence of algae biomass and abundance of filamentous algae that was highest on light-exposed tiles during the present study (Jessen et al. 2013a). While these filamentous algae can prevent invertebrate settlement (Arnold et al. 2010; Glasby \& Connell 2001; Virgilio et al. 2006), encrusting algae, i.e., CCAs, often facilitate and induce invertebrate settlement (Arnold et al. 2010; Heyward \& Negri 1999; Morse et al. 1996; Negri et al. 2001; Whalan et al. 2012).

237 Correspondingly, encrusting algae were not observed on the light-exposed tiles, but were 238 abundant on the shaded tiles, particularly in non-caged treatments ( 239 Nevertheless, invertebrates were obviously present on light-exposed substrate in natural reefs. It 240 may be that adequate settlement substratum for CCA exhibit delayed growth on light-exposed 241 underground (Smith et al. 2010) and thereby delaying sessile invertebrate settlement. This 242 suggests the need for studies over longer time spans to study invertebrate settlement on light243 exposed substrata. While other invertebrate groups that are typically associated with coral reefs 
244 including sponges, soft corals, crustaceans, and ascidians were absent in this experiment, they

245 were found in other, though longer lasting, similar experiments (e.g., Sawall et al. 2013). Their

246 lack in this study may be either explained by the absence of reproduction events during the study

247 period or delayed settlement on artificial substrata as suggested by the observation of ascidians

248 on a spare tile after 16 weeks.

249 The absence of all hard coral settlement in the simulated overfishing treatments may be caused by 250 the presence of more competitive invertebrates that prevented settlement or covered corals 251 (Birkeland 1977; Sawall et al. 2013), filamentous algae (스old et al. 2010; Birrell et al. 2005;

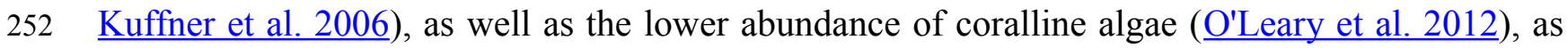
253 these factors were significantly influenced by simulated overfishing on the same tiles (Jessen et 254 al. 2013a).

255 In a recent review, Cooper et al. (2009) summarized and evaluated potential bioindicators for 256 coral reef health and water quality, ranging from species presence and composition to 257 physiological and isotopic parameters. Although their review included coral recruitment, other 258 sessile invertebrates were not considered. The findings of the present study suggest settlement of 259 coral reef associated sessile invertebrates as specific bioindicators for overfishing and a 260 combination of that with eutrophication. For overfishing, this may be an increase in polychaete 261 settlement and a decrease for that of hard corals. For eutrophication the sole decrease of hard 262 coral settlement, and for a combination of both stressors this may be an increase in bryozoan and 263 bivalve settlement. Advantages of this approach would be the cost-effective and relative easy 264 measurement together with low systematic knowledge that is needed to identify the taxonomic 265 groups.

266 As settlement is only one process in the successful recruitment of an organism, it could be 267 interesting to compare the profiteers of the different treatments in this study with known juvenile 
268 mortality rates. This would allow improving predictions on potential sessile invertebrate 269 outbreaks or phase shifts.

270 Studies showed that hard coral settlement experiences up to $100 \%$ mortality within the first year 271 with regional differences: e.g., in French Polynesia 19-56 \% over 14 months (Penin et al. 2010), 272 in Jamaica 91-95 \% over 9-10 months (ylaarsdam 1983), in Florida (annual) 22-49 \% (Miller et 273 al. 2000), in Bonaire $32 \%$ over 6 months (Bak \& Engel 1979), in the Great Barrier Reef (annual)

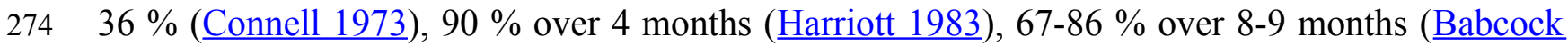
275 1985), and 96-99\% over 4 months (Babcock \& Mundy 1996). The outcomes from non-coral 276 invertebrates from other ecosystems were similar with many studies reporting mortalities of $>90$ $277 \%$ (reviewed in Gosselin \& Qian 1997).

278 To conclude, although the reef appears to be in healthy condition, non-coral invertebrates such as 279 polychaetes or bivalves and bryozoans may rival hard coral dominance at shaded reef locations if 280 simulated threats are not controlled in the study area. This can lead to phase-shifts, potential 281 alternative stable states that may impact the ecology of coral reefs (Norström et al. 2009). 


\section{Acknowledgements}

Many thanks for support go to the CMOR team at KAUST, L. Smith, F. Mallon, E. Aravantinos, and the boat crew K. Al-Moullad, E. Al-Jahdali, G. Al-Jahdali. We also would like to acknowledge the field and laboratory assistance of C. Roder, J. F. Villa Lizcano, A. Roik, C. Arif, M. Kruse, and C. Jhen. For invaluable advice and support in the laboratory we thank N. Fayad, M. Masry, D. Dassbach, and M. Birkicht.

\section{Reference List}

Arnold SN, Steneck RS, and Mumby PJ. 2010. Running the gauntlet: inhibitory effects of algal turfs on the process of coral recruitment. Marine Ecology Progress Series 414:91-105.

Babcock R. 1985. Growth and mortality in juvenile corals (Goniastrea, Platygyra and Acropora): the first year. Proceedings of the 5th International Coral Reef Symposium 4:355-360.

Babcock R, and Mundy C. 1996. Coral recruitment: consequences of settlement choice for early growth and survivorship in two scleractinians. Journal of Experimental Marine Biology and Ecology 206:179-201.

Bak RPM, and Engel MS. 1979. Distribution, abundance and survival of juvenile hermatypic corals (Scleractinia) and the importance of life history strategies in the parent coral community. Marine Biology 54:341-352.

Berumen ML, Hoey AS, Bass WH, Bouwmeester J, Catania D, Cochran JEM, Khalil MT, Miyake S, Mughal MR, Spaet JLY et al. . 2013. The status of coral reef ecology research in the Red Sea. Coral Reefs:1-12.

Birkeland C. 1977. The importance of rate of biomass accumulation in early successional stages of benthic communities to the survival of coral recruits. Proceedings of the $3 \mathrm{rd}$ International Coral Reef Symposium 1:15-21.

Birrell CL, McCook L, and Willis B. 2005. Effects of algal turfs and sediment on coral settlement. Marine Pollution Bulletin 51:408-414.

Burke LM, Reytar K, Spalding M, and Perry A. 2011. Reefs at Risk Revisited. Washington, DC: World Resources Institute.

Burkepile DE, and Hay ME. 2006. Herbivore vs. nutrient control of marine primary producers: context-dependent effects. Ecology 87:3128-3139.

Burkepile DE, and Hay ME. 2007. Predator release of the gastropod Cyphoma gibbosum increases predation on gorgonian corals. Oecologia 154:167-173.

Chadwick NE, and Morrow KM. 2011. Competition among sessile organisms on coral reefs. In: Dubinsky Z, and Stambler N, eds. Coral Reefs: An Ecosystem in Transition. Amsterdam: Springer, 347-371.

Connell JH. 1973. Population ecology of reef-building corals. In: Jones OA, and Endean R, eds. Biology and geology of coral reefs. New York: Academic Press, 205-245.

Connell SD, and Anderson M. 1999. Predation by fish on assemblages of intertidal epibiota: effects of predator size and patch size. Journal of Experimental Marine Biology and Ecology 241:15-29. 
Cooper TF, Gilmour JP, and Fabricius KE. 2009. Bioindicators of changes in water quality on coral reefs: review and recommendations for monitoring programmes. Coral Reefs 28:589-606.

Dahms H-U, Dobretsov S, and Qian P-Y. 2004. The effect of bacterial and diatom biofilms on the settlement of the bryozoan Bugula neritina. Journal of Experimental Marine Biology and Ecology 313:191-209.

Diaz-Pulido G, Harii S, McCook L, and Hoegh-Guldberg O. 2010. The impact of benthic algae on the settlement of a reef-building coral. Coral Reefs 29:203-208.

Glasby T, and Connell SD. 2001. Orientation and position of substrata have large effects on epibiotic assemblages. Marine Ecology Progress Series 214:127-135.

Glynn P. 1990. Feeding ecology of selected coral-reef macroconsumers: patterns and effects on coral community structure. In: Dubinsky Z, ed. Ecosystems of the World 25: Coral Reefs. New York: Elsevier, 365-391.

Gosselin LA, and Qian P-Y. 1997. Juvenile mortality in benthic marine invertebrates. Marine Ecology Progress Series 146:265-282.

Hadfield MG. 2011. Biofilms and marine invertebrate larvae: what bacteria produce that larvae use to choose settlement sites. Annual Review of Marine Science 3:453-470.

Hallock P, and Schlager W. 1986. Nutrient excess and the demise of coral reefs and carbonate platforms. Palaios 1:389-398.

Harrington L, Fabricius K, De'ath G, and Negri A. 2004. Recognition and selection of settlement substrata determine post-settlement survival in corals. Ecology 85:3428-3437.

Harriott VJ. 1983. Reproductive seasonality, settlement, and post-settlement mortality of Pocillopora damicornis (Linnaeus), at Lizard Island, Great Barrier Reef. Coral Reefs 2:151-157.

Harrison P, and Wallace C. 1990. Reproduction, dispersal and recruitment of scleractinian corals. Ecosystems of the World 25:133-207.

Hay ME. 1984. Patterns of fish and urchin grazing on Caribbean coral reefs: are previous results typical? Ecology 65:446-454.

Heyward AJ, and Negri AP. 1999. Natural inducers for coral larval metamorphosis. Coral Reefs 18:273-279.

Hixon MA, and Brostoff WN. 1996. Succession and herbivory: effects of differential fish grazing on Hawaiian coral-reef algae. Ecological Monographs 66:67-90.

Hunte W, and Wittenberg M. 1992. Effects of eutrophication and sedimentation on juvenile corals. Marine Biology 114:625-631.

Jessen C, Roder C, Villa Lizcano J, Voolstra CR, and Wild C. 2012. Top-down and bottom-up effects on Red Sea coral reef algae. Proceedings of the 12th International Coral Reef Symposium.

Jessen C, Roder C, Villa Lizcano JF, Voolstra CR, and Wild C. 2013a. In-Situ Effects of Simulated Overfishing and Eutrophication on Benthic Coral Reef Algae Growth, Succession, and Composition in the Central Red Sea. PLOS ONE 8:e66992.

Jessen C, Villa Lizcano JF, Bayer T, Roder C, Aranda M, Wild C, and Voolstra CR. 2013b. InSitu Effects of Eutrophication and Overfishing on Physiology and Bacterial Diversity of the Red Sea Coral Acropora hemprichii. PLOS ONE 8:e62091.

Kohler KE, and Gill SM. 2006. Coral Point Count with Excel extensions (CPCe): A Visual Basic program for the determination of coral and substrate coverage using random point count methodology. Computers \& Geociences 32:1259-1269.

Kriwy P, and Uthicke S. 2011. Microbial diversity in marine biofilms along a water quality gradient on the Great Barrier Reef. Systematic and Applied Microbiology 34:116-126. 
Kuffner I, Walters L, Becerro M, Paul V, Ritson-Williams R, and Beach K. 2006. Inhibition of coral recruitment by macroalgae and cyanobacteria. Marine Ecology Progress Series 323:107-117.

Lewis LS, and Anderson TW. 2012. Top-down control of epifauna by fishes enhances seagrass production. Ecology 93:2746-2757.

Loya Y, Lubinevsky H, Rosenfeld M, and Kramarsky-Winter E. 2004. Nutrient enrichment caused by in situ fish farms at Eilat, Red Sea is detrimental to coral reproduction. Marine Pollution Bulletin 49:344-353.

McClanahan TR, and Shafir SH. 1990. Causes and consequences of sea urchin abundance and diversity in Kenyan coral reef lagoons. Oecologia 83:362-370.

Miller M, Weil E, and Szmant A. 2000. Coral recruitment and juvenile mortality as structuring factors for reef benthic communities in Biscayne National Park, USA. Coral Reefs 19:115-123.

Miller MW, Hay ME, Miller SL, Malone D, Sotka EE, and Szmant AM. 1999. Effects of nutrients versus herbivores on reef algae: a new method for manipulating nutrients on coral reefs. Limnology and Oceanography 44:1847-1861.

Morse ANC, Iwao K, Baba M, Shimoike K, Hayashibara T, and Omori M. 1996. An ancient chemosensory mechanism brings new life to coral reefs. Biological Bulletin 191:149-154.

Mullineaux L, and Garland E. 1993. Larval recruitment in response to manipulated field flows. Marine Biology 116:667-683.

Myers RA, Baum JK, Shepherd TD, Powers SP, and Peterson CH. 2007. Cascading effects of the loss of apex predatory sharks from a coastal ocean. Science 315:1846-1850.

Negri A, Webster N, Hill R, and Heyward A. 2001. Metamorphosis of broadcast spawning corals in response to bacteria isolated from crustose algae. Marine Ecology Progress Series 223:121-131.

Norström AV, Nyström M, Lokrantz J, and Folke C. 2009. Alternative states on coral reefs: beyond coral-macroalgal phase shifts. Marine Ecology Progress Series 376:295-306.

O'Leary JK, Potts DC, Braga JC, and McClanahan TR. 2012. Indirect consequences of fishing: reduction of coralline algae suppresses juvenile coral abundance. Coral Reefs 31:547-559.

Osman RW, and Whitlatch RB. 1995. The influence of resident adults on recruitment: a comparison to settlement. Journal of Experimental Marine Biology and Ecology 190:169198.

Penin L, Michonneau F, Baird AH, Connolly SR, Pratchett MS, Kayal M, and Adjeroud M. 2010. Early post-settlement mortality and the structure of coral assemblages. Marine Ecology Progress Series 408:55-64.

Posey MH, Alphin TD, Cahoon LB, Lindquist DG, Mallin MA, and Nevers MB. 2002. Top-down versus bottom-up limitation in benthic infaunal communities: direct and indirect effects. Estuaries 25:999-1014.

RDC. Team (R Development Core Team) (2012) R: A Language and Environment for Statistical Computing (Vienna: R Foundation for Statistical Computing). http://www.r-project.org/.

Rylaarsdam KW. 1983. Life histories and abundance patterns of colonial corals on Jamaican reefs. Marine Ecology 13:249-260.

Sawall Y, Jompa J, Litaay M, Maddusila A, and Richter C. 2013. Coral recruitment and potential recovery of eutrophied and blast fishing impacted reefs in Spermonde Archipelago, Indonesia. Marine Pollution Bulletin 74:374-382.

Sawall Y, Richter C, and Ramette A. 2012. Effects of Eutrophication, Seasonality and Macrofouling on the Diversity of Bacterial Biofilms in Equatorial Coral Reefs. PLOS ONE 7:e39951. 
Smith J, Smith C, and Hunter C. 2001. An experimental analysis of the effects of herbivory and nutrient enrichment on benthic community dynamics on a Hawaiian reef. Coral Reefs 19:332-342.

Smith JE, Hunter CL, and Smith CM. 2010. The effects of top-down versus bottom-up control on benthic coral reef community structure. Oecologia 163:497-507.

Tomascik T. 1991. Settlement patterns of Caribbean scleractinian corals on artificial substrata along a eutrophication gradient, Barbados, West Indies. Marine Ecology Progress Series 77:261-269.

Tran C, and Hadfield MG. 2011. Larvae of Pocillopora damicornis (Anthozoa) settle and metamorphose in response to surface-biofilm bacteria. Marine Ecology Progress Series 433:85-96.

Tribollet A, and Golubic S. 2011. Reef bioerosion: agents and processes. In: Dubinsky Z, and Stambler N, eds. Coral Reefs: An Ecosystem in Transition. Amsterdam: Springer, 435449.

Vine PJ. 1974. Effects of algal grazing and aggressive behaviour of the fishes Pomacentrus lividus and Acanthurus sohal on Coral-Reef Ecology. Marine Biology 24:131-136.

Vine PJ. 1986. Red Sea Invertebrates. London: Immel Publishing.

Vine PJ, and Bailey-Brock JH. 1984. Taxonomy and ecology of coral reef tube worms (Serpulidae, Spirorbidae) in the Sudanese Red Sea. Zoological Journal of the Linnean Society 80:135-156.

Virgilio M, Airoldi L, and Abbiati M. 2006. Spatial and temporal variations of assemblages in a Mediterranean coralligenous reef and relationships with surface orientation. Coral Reefs 25:265-272.

Webster NS, Smith LD, Heyward AJ, Watts JEM, Webb RI, Blackall LL, and Negri AP. 2004. Metamorphosis of a scleractinian coral in response to microbial biofilms. Applied and Environmental Microbiology 70:1213-1221.

Whalan S, Webster NS, and Negri AP. 2012. Crustose coralline algae and a cnidarian neuropeptide trigger larval settlement in two coral reef sponges. PLOS ONE 7:e30386.

Witt V, Wild C, and Uthicke S. 2012a. Interactive climate change and runoff effects alter $\mathrm{O} 2$ fluxes and bacterial community composition of coastal biofilms from the Great Barrier Reef. Aquatic Microbial Ecology 66:117-131.

Witt V, Wild C, and Uthicke S. 2012b. Terrestrial runoff controls the bacterial community composition of biofilms along a water quality gradient in the Great Barrier Reef. Applied and Environmental Microbiology 78:7786-7791.

Yang J-L, Shen P-J, Liang X, Li Y-F, Bao W-Y, and Li J-L. 2013. Larval settlement and metamorphosis of the mussel Mytilus coruscus in response to monospecific bacterial biofilms. Biofouling 29:247-259.

Zuur AF, Ieno EN, Walker NJ, Saveliev AA, and Smith GM. 2009. Mixed effects models and extensions in ecology with $R$. New York: Springer. 


\section{Figure 1}

Schematic drawing of the experimental setup.

Shown is a PVC frame equipped with twelve tiles (two of them spare tiles) half of them in light exposed conditions and half of them in light shaded conditions. The dotted line shows where the glazed side of the tile (inward pointing side) has been pre-scored to facilitate tile division upon sampling.

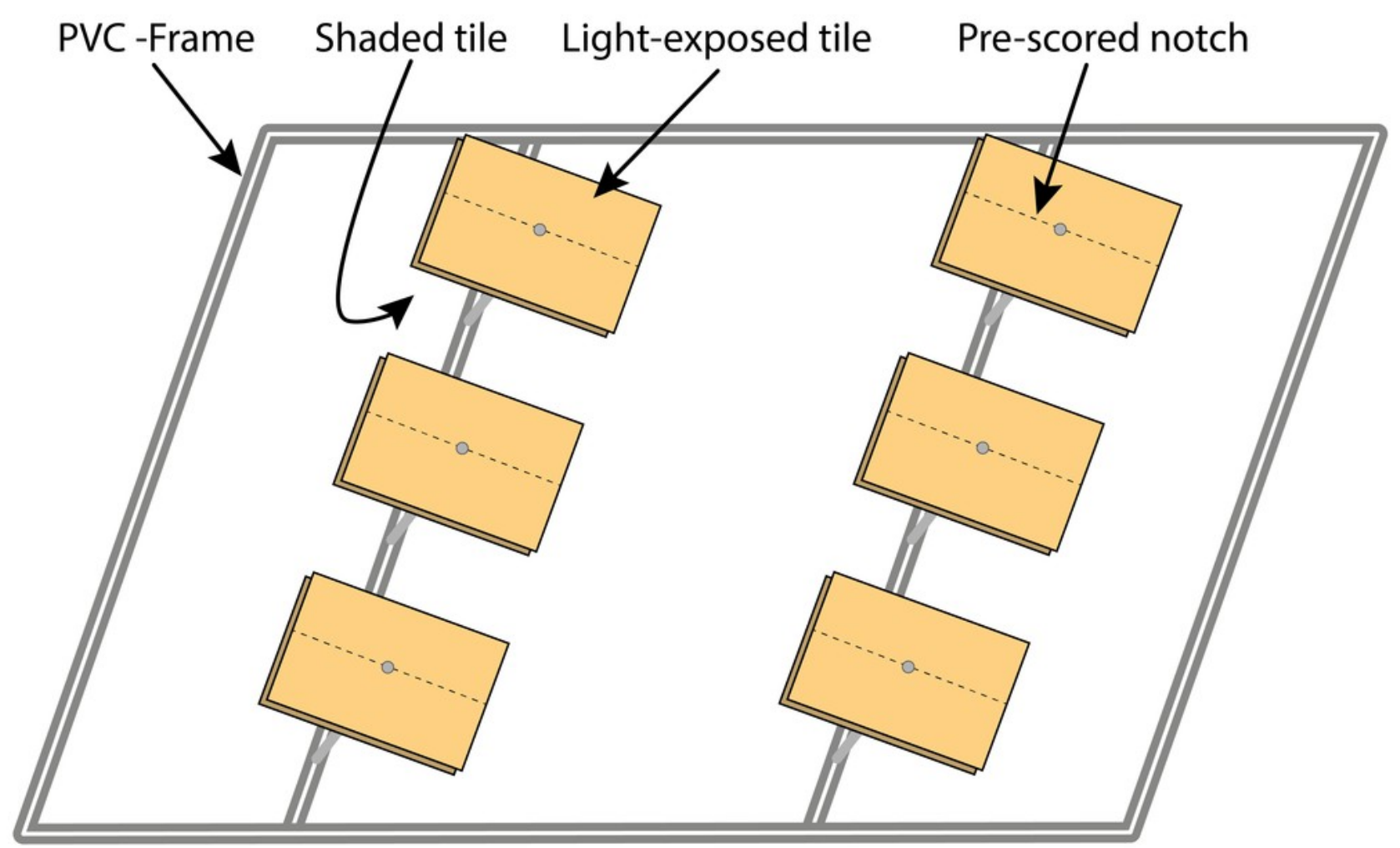




\section{Figure 2}

Invertebrate settlement numbers (depicted per $\mathrm{cm}^{-2}$; mean $\pm \mathrm{SE}$ ) on shaded tiles.

Left column (A, C, E, G) shows settlement numbers per treatment averaged over all tiles and right column (B, D, F, H) shows temporal development of counted recruits of all 4 treatments. P-values were calculated from a 3-factorial GLM and originate from analysis across the whole study period (see Table S1 for full results). Dashes represent factors that have been excluded by the model reduction. Abbreviations: $\mathrm{C}=\mathrm{C}$ age, $\mathrm{F}=\mathrm{Fertilizer,} \mathrm{T}=\mathrm{Time}$. Treatments with same small letters are not significantly different $(p>0.05)$ in post hoc pairwise comparisons. 

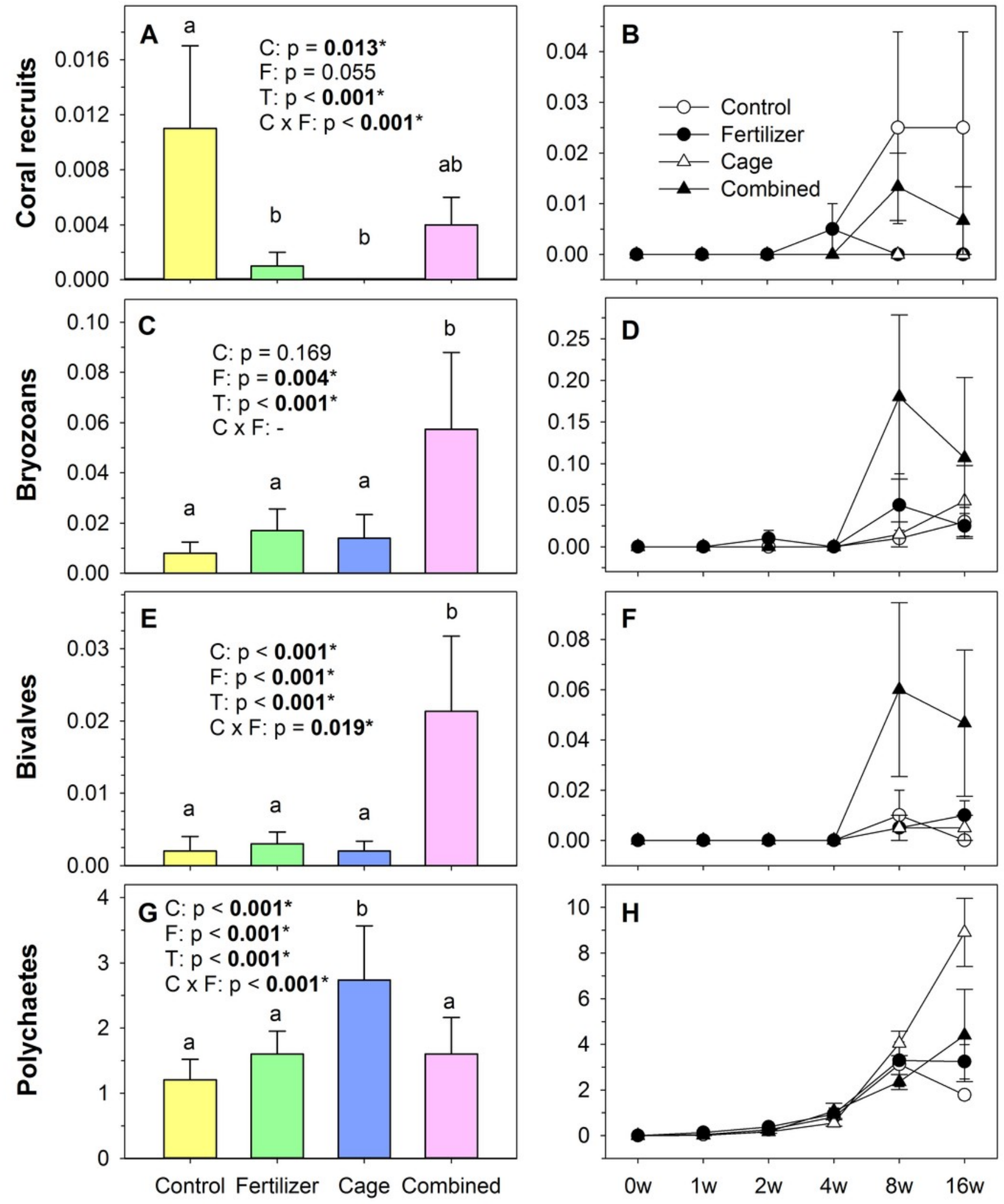


\section{Figure 3}

Representative photographs of light-shaded tiles after 16 weeks of deployment in the reef.

White bars in the central upper right area of each picture are reflections caused by a camera flash. Hemi-circle holes at the central lower edge were used for screws to attach tiles. According to a point count analysis ran in Coral Point Count with Excel extensions (CPC), average invertebrate cover did not exceed $8 \%$. See Jessen et al. (2013a) for full results.

Control

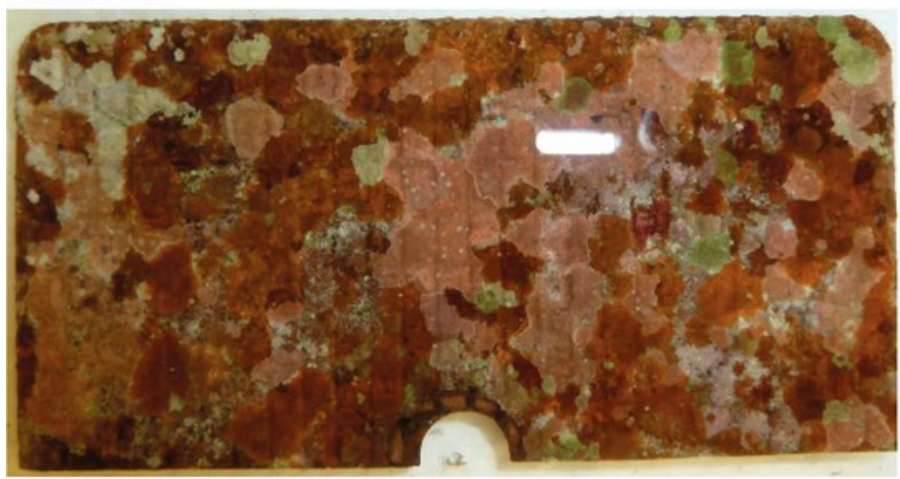

\section{Simulated Overfishing}

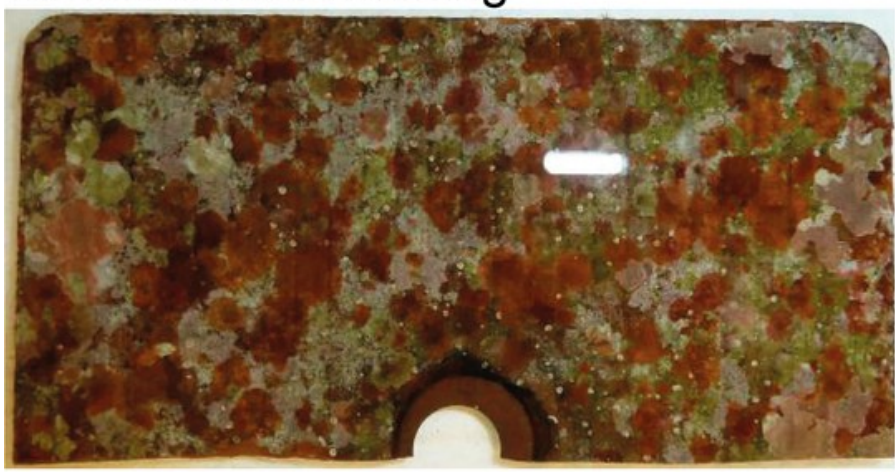

Simulated Eutrophication

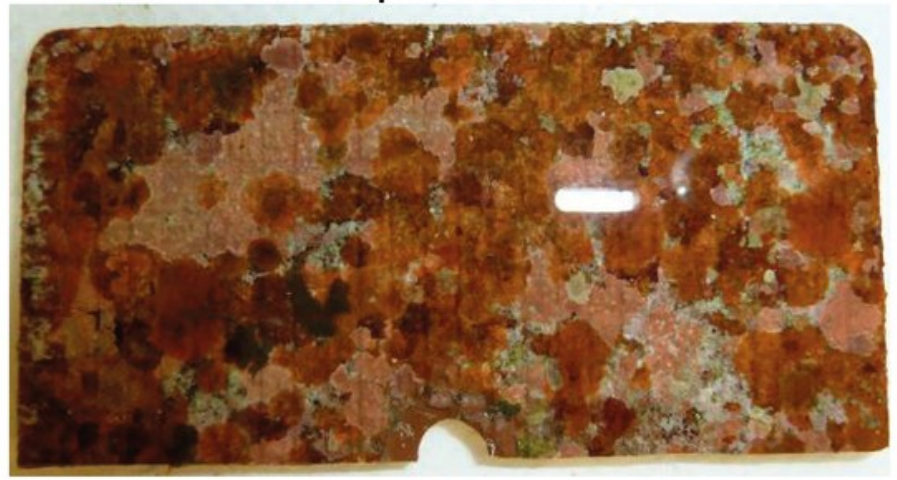

Combined Treatment

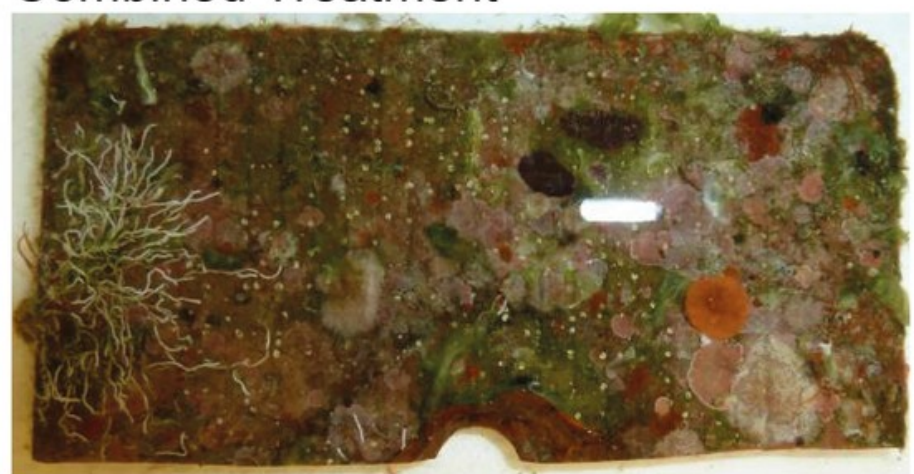

